\title{
RECREATIONAL AND HEALTH FORESTS OF KREMENETS DISTRICT, TERNOPIL REGION
}

\author{
O. Bondar \\ Candidate of Agricultural Sciences \\ Taras Shevchenko Regional Humanitarian-Pedagogical Academy of Kremenets (Kremenets, \\ Ukraine) \\ e-mail: olexandr.bondar@i.ua; ORCID: https://orcid.org/0000-0002-3448-8943 \\ N. Tsytsiura \\ Candidate of Biological Sciences \\ Taras Shevchenko Regional Humanitarian-Pedagogical Academy of Kremenets \\ (Kremenets, Ukraine) \\ e-mail: smaragds@ukr.net; ORCID: https://orcid.org/0000-0002-8663-6397
}

The article presents the results of the research of recreational and health stands in Kremenets district of Ternopil region. The total area of these forests is 5868.2 hectares.

Studies of the typological structure of the forests were carried out according to the methods of AlekseevPohrebniak Forest Typology of Forestry Ecological School. MapInfo Professional 12.0 and a vector map of Ukraine were used to construct a map-scheme of the research region.

The typological variety of recreational and health-improving stands is represented from subors (B) to dubravas (D). Thus, dubravas are the largest share among them $(72.9 \%$ of the total area covered with forest vegetation). The share of the area of sudubravas is $17.7 \%$ of the total area covered with forest vegetation; the rest is subors $(9.4 \%)$.

Forest managers have identified 14 types of forests on the territory of the research facility. Thus, there are only 2 types of forest in the subors, 8 types of forest in the sudubravas and 4 types of forests in the dubravas.

The most common type of forest in Kremenets district is fresh hornbeam forest represented $71.6 \%$ of the total area covered with forest vegetation. The share of fresh hornbeam-oak-pine forest reaches $17.1 \%$; a slightly smaller share is represented by fresh oak-pine subors - 9.4\%.

The forest species diversity is represented by 22 species of trees. Thus, among these tree species, the largest area is occupied by Common Oak (Quercus robur L.) - $40.6 \%$ of the total area covered with forest vegetation, and $29.1 \%$ - by Scots Pine (Pinus sylvestris L.).

Stands of artificial origin (78.0\% of the total area covered with forest vegetation) are dominant; the rest of stands have natural origin (22.0\%).

The age structure of stands is unbalanced. Middle-aged stands dominate (57.9\% of the total area covered with forest vegetation). The share of maturing, young and matured forests ranges from 9.0 to $14.9 \%$ of the total forest area.

In terms of relative completeness, stands with a density of 0.71-0.8 dominate which is $37.7 \%$ of the total area covered with forest vegetation. The share of stands with completeness of 0.61-0.7 (29.9\%) and 0.81-0.9 (14.5\%) is slightly smaller.

The bonitete classes are dominated by stands of the I bonitete class $-51.3 \%$ of the total area covered with forest vegetation. Thus, the share of II, Ia and III bonitete classes varies from 7.1 to $23.3 \%$ of the total forest area.

Keywords: stands, forest type, forestry and tax indicators, forest typology, relative completeness, bonitete class.

\section{INTRODUCTION}

Recreational and health forests include forest areas, "which perform recreational, sanitaryhygienic and health-improving function, they are used for tourism, sports, sanatorium treatment and recreation of the population and located:

- within cities, towns and other localities;

- within the districts of sanitary protection of medical and health territories and resorts;
- within the strips of sanitary protection zones of water bodies;

- in the green zone forests around the towns and cities;

- outside the green zone forests»[10].

The aim of the study was to analyze the distribution, typological and forestry-taxation structure of recreational and health forests in Kremenets district. 


\section{ANALYSIS OF RECENT RESEARCH AND PUBLICATIONS}

The study of recreational and health forests has been revealed in the scientific works of V.P. Voron [5], S.I. Myklush [6], M.M. Kutia [4], I.F. Kalutsky [3], T.S. Pavlovskaya [8], M.R. Pytulyak [9], S.I. Musienko [7], T. Gerstenberg [11], J. Oppliger [12], G.S. Russo [13], H. Tavárez [14], L. Tuffery [15], L. Tyrväinen [16] and others.

The area of recreational and health stands in Ternopil region reaches 27 thousand hectares. Thus, the largest area of forests is concentrated in the central part of the region - in SE «Ternopil $\mathrm{FE}$ » (12.4 thousand hectares) and $\mathrm{SE}$ «Chortkiv $\mathrm{FE}$ »(7.9 thousand hectares). Stands is an important component of biotic resources used for recreational and tourist activities in the Ternopil region very actively [9]. However, it is still important to conduct complex research to study the typological and forest-taxonomic structure of recreational and health forests in Kremenets district of Ternopil region.

\section{MATERIALS AND RESEARCH METHODS}

The analysis of various cartographic materials (topographic, vector maps, atlases) and forest management materials (taxonomic materials, afforestation plans) was conducted in order to study the recreational and health forests in Kremenets district of Ternopil region.
The MapInfo Professional 12.9 geographic information system and the vector map of Ternopil region with a detailed refinement on 1: 25000 scale maps were used to highlight the boundaries of Kremenets district.

The research of the typological and forestry-taxation structure of recreational and health stands was carried out on the basis of the materials of the excretory database of PA «Ukrderzhlisproekt» (as of 01.01.2016). The database has 1505 quarters. Conversion of database files of the production association «Ukrderzhlisproekt» from *vff format into *molb format was carried out with the help of the developed program of UkrRIFFM named after G.M. Vysotsky [2].

Forestry-typological analysis of forests was carried out in accordance with the main methodological provisions of forestry-ecological (Ukrainian) school of forest typology [2].

\section{RESULTS AND DISCUSSION}

The research covered the forest fund of forestry enterprises within Ternopil region. Geographical coordinates of the extreme points of the research region: in the North - 26 $6^{\circ} 3^{\prime} 28^{\prime \prime}$, $50^{\circ} 16^{\prime} 07^{\prime \prime}$, in the South - 25 $56^{\prime} 45^{\prime \prime}, 49^{\circ} 41^{\prime} 57^{\prime \prime}$, in the West - $25^{\circ} 21^{\prime} 02^{\prime \prime}, 50^{\circ} 0^{\prime} 15^{\prime \prime}$ and in the East $26^{\circ} 16^{\prime} 29^{\prime \prime}, 50^{\circ} 06^{\prime} 22^{\prime \prime}$ (Fig. 1).

The total area of the studied forests is 5868.2 hectares which are subordinated to the

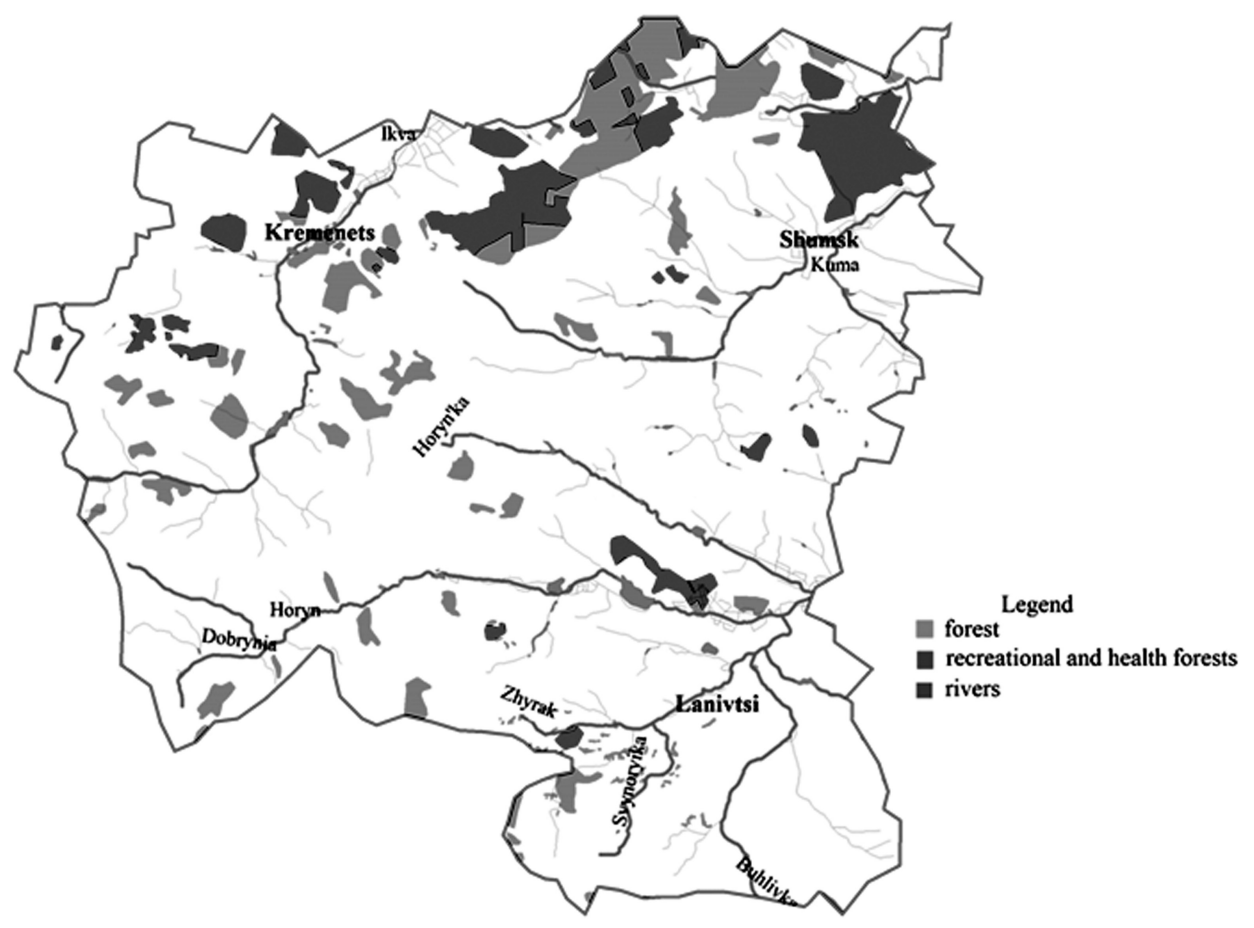

Fig. 1. Scheme-map of recreational and health forests of Kremenets district Source: developed by the authors based on their own research. 


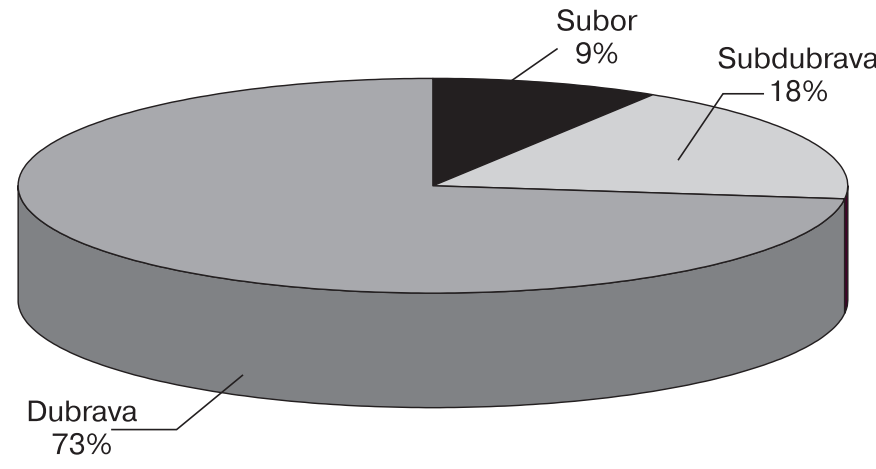

Fig. 2. Distribution of the area of recreational and health forests according to the trophotopes

Source: PA «Ukrderzhlisproekt» database (as of 01.01.2016).

State Agency of Forest Resources of Ukraine. The trophogenic series from subors to dubravas has been represented on the territory of the research object. Among the trophotopes the largest area is occupied by $\mathrm{s}-72.9 \%$. The share of the area of sudubravas is $17.7 \%$ of the total area covered with forest vegetation, the rest are subors $-9.4 \%$ (Fig. 2).

As a result of the analysis of the areas of stands on the territory of the research object according to the hygrotopes, it was determined that the subors are represented by fresh and moist hygrotopes. Thus, their share is $9.4 \%$ of the total area covered with forest vegetation.

In Kremenets district fresh and moist hydrotopes predominate in the composition of sudubravas. Thus, the share of fresh dubravas is $17.3 \%$ of the total area covered with forest vegetation. The share of dry, moist, damp and wet hygrotope occupy small areas (up to $1.0 \%$ of the total forest area).

Dubrvas are represented by dry, fresh moist and damp hygrotopes. Thus, fresh dubrava occupies $71.6 \%$ of the total area covered with forest vegetation. The total share of dry, moist and damp dubravas is approximately $1.2 \%$ of the total area covered with forest vegetation.

The analysis of the distribution of the area covered with forest vegetation according to the forest types shows that the most common type of forest on the research territory is fresh hornbeam dubrava $\left(\mathrm{D}_{2}-\mathrm{hD}\right)$, represented $71.6 \%$ of the total area covered with forest vegetation.

Fresh hornbeam-oak-pine sudubrava $\left(\mathrm{C}_{2}\right.$-hoS $)$ occupies $17.1 \%$ of the land covered with forest vegetation. A large area of the research terrtory is occupied by fresh oak and pine subor $(9.4 \%)$ amd moist hornbeam wood (1.2\% of the total area covered with forest vegetation).

The share of moist oak-pine soubor $\left(\mathrm{B}_{3}-\mathrm{oP}\right)$, dry eroded sudubrava $\left(\mathrm{C}_{1}-\mathrm{Oe}\right)$, fresh hornbeam dubrava $\left(\mathrm{C}_{2}-\mathrm{hD}\right)$, moist hornbeam dubrava $\left(\mathrm{C}_{3}-\mathrm{hD}\right)$, moist hornbeam-oak-pine sogrud $\left(\mathrm{C}_{3}\right.$-hoP) ), fresh hornbeam-pine sudibrova $\left(\mathrm{C}_{3}-\mathrm{hpS}\right)$, damp black alder sudubrava $\left(\mathrm{C}_{4}-\mathrm{A}\right)$, wet black alder sudbrava $\left(\mathrm{C}_{5}-\mathrm{A}\right)$, dry hornbeam dubrava $\left(\mathrm{D}_{1}-\mathrm{hO}\right)$ and damp black alder grud $\left(\mathrm{D}_{4}-\mathrm{A}\right)$ (Table 1$)$.

The species diversity of forests on the territory of the research object is represented by 22 species of trees. Thus, among these tree species the largest area is occupied by Common Oak (Quercus robur L.) - 40.6\% and Scots Pine (Pinus sylvestris $\mathrm{L}$.) $-29.1 \%$ (Table 2 ).

The share of Hanging Birch (Betula pendula Roth.), Common Hornbeam (Carpinus betulus L.), Red Oak (Quercus rubra L.), Pseudoplatane Maple (Acer platanoides L.), European Larch (Larix decidua Mill.), European Spruce (Picea abies (L.) H. Karst.) and Common Ash (Fraxinus excelsior L.) ranges from 1.3 to $7.3 \%$ of the total area covered with forest vegetation. The area of the other 13 tree species is only up to $3.0 \%$.

The territory of the research object is dominated by the forests of artificial origin (78.0\% of

Table 1

Distribution of the area of recreational and health forests according to the forest types

\begin{tabular}{|l|c|c|}
\hline \multirow{2}{*}{\multicolumn{1}{|c|}{ Types of forests }} & \multicolumn{2}{c|}{ Area } \\
\cline { 2 - 3 } & acre & \% \\
\hline \hline Fresh oak and pine subor & 552,1 & 9,4 \\
\hline Fresh hornbeam-oak-pine sudubrava & 1005,2 & 17,1 \\
\hline Fresh hornbeam dubrava & 4203,7 & 71,6 \\
\hline Moist hornbeam dubrava & 70,4 & 1,2 \\
\hline Others & 36,8 & 0,7 \\
\hline Total & 5868,2 & 100,0 \\
\hline
\end{tabular}

Source: PA «Ukrderzhlisproekt» database (as of 01.01.2016). 
Distribution of the area of recreational and health forests according to the tree species

\begin{tabular}{|l|c|c|}
\hline \multirow{2}{*}{\multicolumn{1}{c|}{ Tree species }} & \multicolumn{2}{c|}{ Area } \\
\cline { 2 - 3 } & acre & \% \\
\hline \hline Hanging Birch & 93,5 & 1,6 \\
\hline Common Hornbeam & 476,1 & 8,1 \\
\hline Common Oak & 2384,3 & 40,6 \\
\hline Red Oak & 224,6 & 3,8 \\
\hline Pseudoplatane Maple & 118,2 & 2,0 \\
\hline European Larch & 73,5 & 1,3 \\
\hline Scots Pine & 1708,1 & 29,1 \\
\hline European Spruce & 193,3 & 3,3 \\
\hline Common Ash & 431,2 & 7,3 \\
\hline Others & 165,4 & 2,9 \\
\hline Total & 5868,2 & 100,0 \\
\hline
\end{tabular}

Source: PA «Ukrderzhlisproekt» database (as of 01.01.2016).

the total area covered with forest vegetation), the rest - of natural origin (22.0\%).

Recreational and health forests of Kremenets district are divided into two subcategories (Fig. 3). Thus, among them the largest share is represented by the stands of forestry part of green zones ( $90.4 \%$ of the total area covered with forest vegetation), 9.4 times smaller is the area of the forest-park part of green zone forests $(9.6 \%)$.

According to the results of the study conducted on the research object it was established that the forest fund is characterized by an unbalanced age structure of forests (Fig. 4). Thus, the share of middle age forests is the largest (57.9\% of the total area covered with forest vegetation).
The share of maturing, young and mature forests ranges from 9.0 to $14.9 \%$ of the total forest area.

The completeness of stands is one of the most important factors that characterizes the level of performance of protective, water-regulating and recreational and health functions of the forest. Thus, the ratio of the shares of precipitation that will be retained by tree crowns, evaporation from tree crowns and transpiration depends on completeness. When increasing the completeness from 0.2 to 0.8 there is a significant reduction in surface runoff - almost 10 times.

The distribution of the area of recreational and health forests in Kremenets district is quite diverse (Fig. 5). Thus, stands with the density of

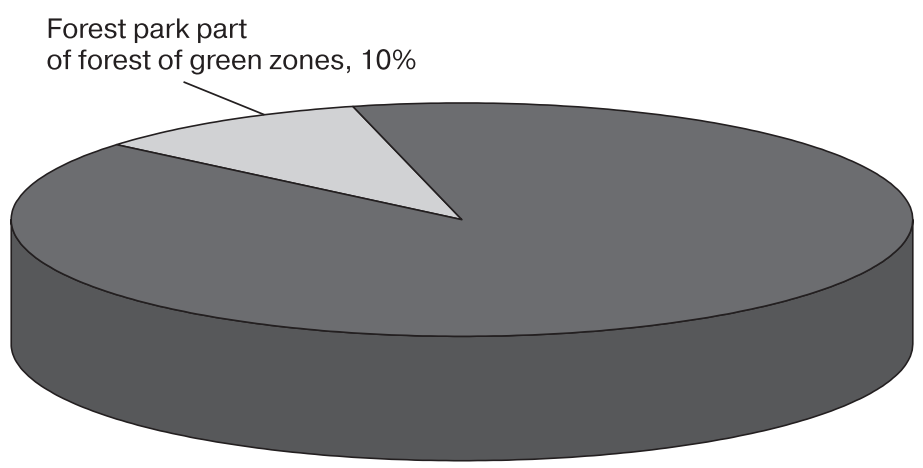

Forest of forest of green zones, $90 \%$

Fig. 3. Distribution of the area of recreational and health forests according to the subcategories, \% Source: PA «Ukrderzhlisproekt» database (as of 01.01.2016). 
Recreational and health forests of kremenets district,

Ternopil Region

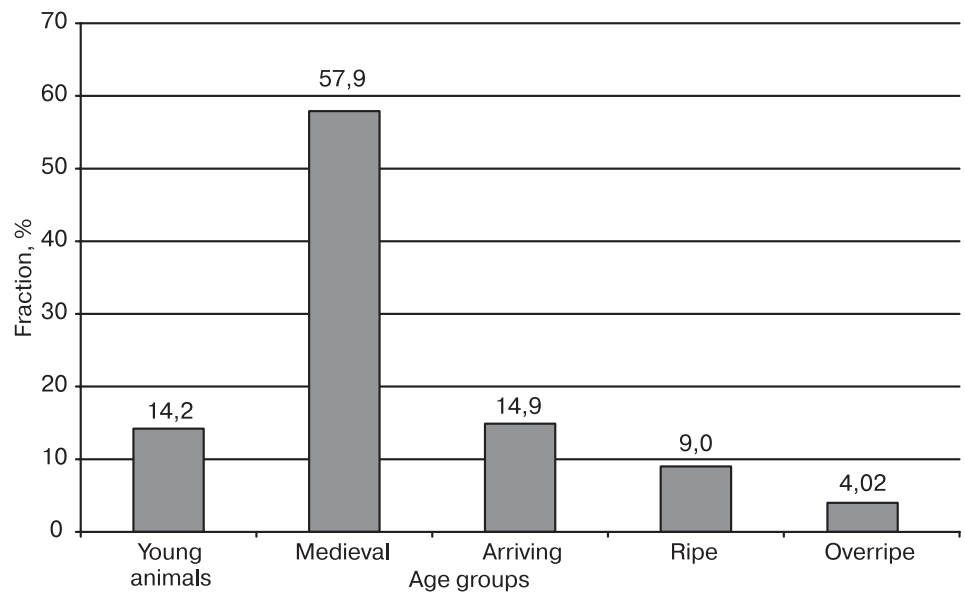

Fig. 4. Distribution of the area of recreational and health forests according to the age groups, \%

Source: PA «Ukrderzhlisproekt» database (as of 01.01.2016).

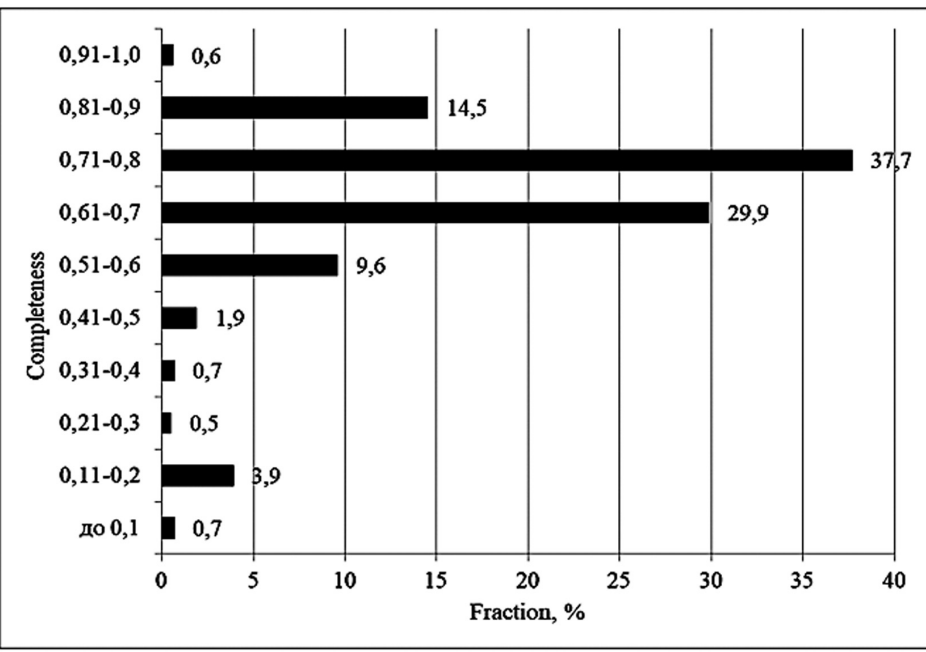

Fig. 5. Distribution of the area of recreational and health forests according to the completeness, \%

Source: PA «Ukrderzhlisproekt» database (as of 01.01.2016).
$0.71-0.8$ dominate, which is $37.7 \%$ of the total area covered with forest vegetation.

Stands with the density of $0.61-0.7$, $0.81-0.9$ and $0.51-0.6$ occupy $29.9,14.5$ and $9.6 \%$ of the total forest area, respectively. The share of completeness from 0.1 to 0.5 and $0.91-1.0$ is negligible.

The analysis of the distribution of the area of stands according to the completeness proves that the structure of treestands on the territory of the research object is dominated by the stands with the density close to optimal in the hydrological and recreational sense.

There are 9 quality classes on the territory of the research object (Fig. 6). The distribution of stands according to the bonitete classes is quite different. Thus, stands of the first bonitete class dominate (51.3\% of the total area covered with forest vegetation).

The share of II, Ia and III bonitete class varies from 7.1 to $23.3 \%$ of the total forest area. In general, the share of other bonitete classes is only $4.2 \%$ of forests.

\section{CONCLUSIONS}

The total area of recreational and health stands of Kremenets district is 5868.2 hectares. Among them there are two subcategories: forestry part of forests of green zones $(90.4 \%$ of the total area covered with forest vegetation) and forest park part of forests of green zones (9.6\%).

The typological structure of recreational and health stands is represented by 14 types of forests. Among them, the most common are fresh hornbeam $(71.6 \%$ of the total area covered with forest vegetation),

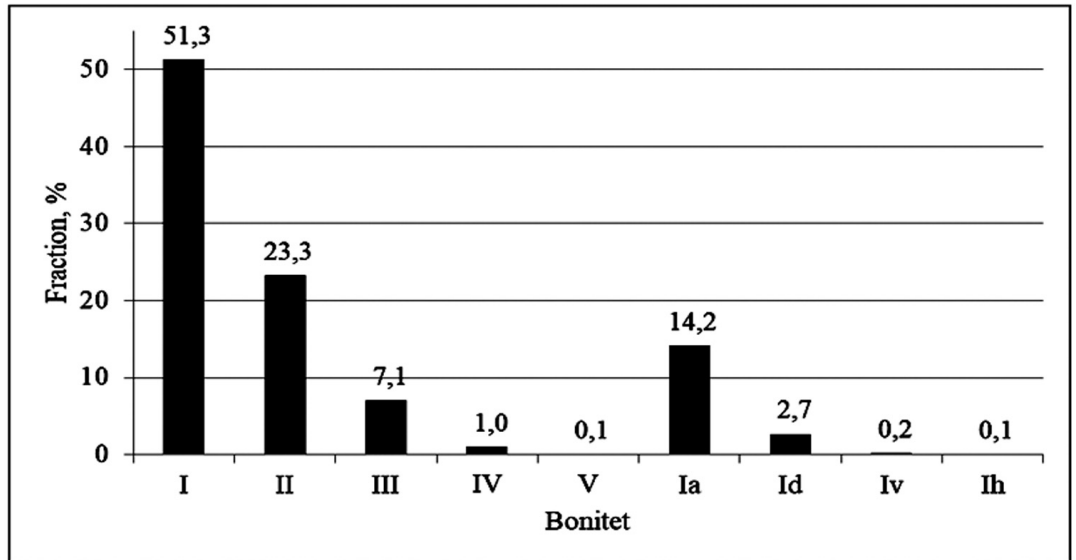

Fig. 6. Distribution of the area of recreational and health forests according to the classes of bonitete, \% Source: PA «Ukrderzhlisproekt» database (as of 01.01.2016). 
fresh hornbeam-oak-pine sudubrava (17.1\%) and fresh oak-pine subor (9.4\%).

Species diversity of recreational and health stands is characterized by 22 species of trees. They are dominated by Common Oak $(40.6 \%$ of the total area covered with forest vegetation) and Scots Pine (29.1\%).
The age structure of recreational and health stands is unbalanced. Middle age stands dominate $(57.9 \%$ of the total area covered with forest vegetation). The share of maturing, young and mature forests varies from 9.0 to $14.9 \%$.

\section{REFERENCES}

1. Bondar, O.B., Tkach, L.I. \& Solodovnyk, V.A. (2019). Lisivnycho-taksatsiina struktura lisiv u DP «Kremenetske LH» [Forestry-taxation structure of forests at the state enterprise «Kremenets forestry»]. Podilskyi visnyk: silske hospodarstvo, tekhnika, ekonomika - Podilian Bulletin: Agriculture, Engineering, Economics, 30, 15-23. DOI: https://doi.org/10.37406/2706-9052-2019-1-2 [in Ukrainian].

2. Vedmid, M.M. \& Raspopina, S.P. (2010) Otsinka lisoroslynnoho potentsialu zemel. Metodychnyi posibnyk [Assessment of forest vegetation potential of lands. Methodical manual]. Kyiv: Vydavnychyi dim «Ekoinform» [in Ukrainian].

3. Kalutskyi, I. (2013). Rekreatsiino-ozdorovchi lisovi resursy Ivano-Frankivshchyny ta shliakhy pokrashchennia yikh vykorystannia [Recreation and wellness forest resources Ivano-Frankivsk and ways of improving their use]. Hirska shkola Ukrainskykh Karpat - Mountain School of Ukrainian Carpathians, 10, 176-178 [in Ukrainian].

4. Kutia, M.MI. \& Hirs, O.A. (2012). Kharakterystyka rekreatsiinykh navantazhen ta rekreatsiinoi mistkosti lisoparkovykh landshaftiv Kyieva [Description of recreational loading and recreational capacity of Kyiv forest park landscapes]. Naukovyi visnyk NLTU Ukrainy - The Scientific Bulletin of UNFU, 22.12, 86-90 [in Ukrainian].

5. Voron, V.P., Ivashyniuta, S.V., Koval, I.M. \& Bondaruk M.A. (2008). Lisy zelenoi zony m. Rivne ta yikh ekoloho-zakhysni funktsii [Forests of the green zone of Rivne and their ecological and protective functions]. Kharkiv: Nove slovo [in Ukrainian].

6. Myklush, S.I. \& Myklush, Yu.S. (2010). Pidkhody do otsinky rekreatsiinykh rivnynnykh bukovykh lisiv [Approaches of assessment of recreational plane beech forests]. Naukovyi visnyk NLTU Ukrainy - The Scientific Bulletin of UNFU, 20.9, 56-60 [in Ukrainian].

7. Musiienko, S.I., Lukianets, V.A., Bondarenko, V.V., Rumiantsev, M.H. \& Kobets, O.V. (2020). Typolohichne riznomanittia rekreatsiino-ozdorovchykh lisiv Livoberezhnoi Ukrainy [Typological diversity of recreational and health-improving forests in Left-Bank Ukraine]. Naukovyi visnyk NLTU Ukrainy - The Scientific Bulletin of UNFU, 30(5), 2020. 31-35. DOI: https://doi.org/10.36930/40300505 [in Ukrainian].

8. Pavlovska, T.S., Biletskyi, Yu.V. \& Viliura, T.S. (2017). Rekreatsiino-ozdorovchi lisy Volynskoi oblasti [Recreational and healtimproving forests of Volyn region] Naukovyi ohliad - Journal scientific review, 4(36), 1-10 [in Ukranian].

9. Pytuliak, M. \& Pytuliak, M. (2017). Osoblyvosti rekreatsiinoho lisokorystuvannia v Ternopilskii oblasti [The peculiarities of the nature forest use in Ternopil region]. Ratsionalne pryrodokorystuvannia i okhorona pryrody. Naukovi zapysky - Rational use of nature and nature protection. Proceedings, 2, 185-190 [in Ukranian].

10. Pro zatverdzhennia Poriadku podilu lisiv na katehorii ta vydilennia osoblyvo zakhysnykh lisovykh dilianok [On approval of the Procedure for division of forests into categories and allocation of specially protected forest areas]. URL: https://zakon.rada.gov.ua/laws/show/733-2007-\%D0\%BF. (Accessed on 12 May 2021) [in Ukranian].

11. Gerstenberg, T., Baumeister, C.F., Schraml, U. \& Plieninger, T. (2020). Hot routes in urban forests: The impact of multiple landscape features on recreational use intensity, Landscape and Urban Planning, 203, 103888. DOI: https://doi.org/10.1016/j.landurbplan.2020.103888 [in English].

12. Oppliger, J., Lieberherr, E. \& Hegetschweiler, K.T. (2019). Factors influencing teenagers' recreational forest use in a densely-populated region in Switzerland. Journal of Outdoor Recreation and Tourism, 27, 100225. DOI: https://doi.org/10.1016/j.jort.2019.100225 [in English].

13. Russo, G.S., Eftim, S.E., Goldstone, A.E., Dufour, A.P., Nappier, S.P. \& Wade, T.J. (2020). Evaluating health risks associated with exposure to ambient surface waters during recreational activities: A systematic review and meta-analysis. Water Research, 176, 115729. DOI: https://doi.org/10.1016/ j.watres.2020.115729 [in English].

14. Tavárez, H. \& Elbakidze, L. (2019) Valuing recreational enhancements in the San Patricio Urban Forest of Puerto Rico: A choice experiment approach. Forest Policy and Economics, 109, 102004. DOI: https:// doi.org/10.1016/j.forpol.2019.102004 [in English].

15. Tuffery, L. (2017). The recreational services value of the nearby periurban forest versus the regional forest environment. Journal of Forest Economics, 28, 33-41. DOI: https://doi.org/10.1016/j.jfe.2017.04.004 [in English]. 
Recreational and health forests of kremenets district,

Ternopil Region

16. Tyrväinen, L., Mäntymaa, E., Juutinen, A., Kurttila, M. \& Ovaskainen, V. (2021) Private landowners' preferences for trading forest landscape and recreational values: A choice experiment application in Kuusamo, Finland. Land Use Policy, 107, 104478. DOI: https://doi.org/10.1016/j.landusepol.2020.104478 [in English].

\section{РЕКРЕАЦІЙНО-ОЗДОРОВЧІ ЛІСИ КРЕМЕНЕЦЬКОГО РАЙОНУ ТЕРНОПІЛЬСЬКОЇ ОБЛАСТІ}

О.Б. Бондар

кандидат сільськогосподарських наук, старший викладач Кременецька обласна гуманітарно-педагогічна академія

ім. Тараса Шевченка (м. Кременець, Україна) e-mail: olexandr.bondar@i.ua; ORCID: https://orcid.org/0000-0002-3448-8943

Н.I. Цицюра

кандидат біологічних наук, доцент

Кременецька обласна гуманітарно-педагогічна академія ім. Тараса Шевченка (м. Кременець, Україна) e-mail: smaragds@ukr.net; ORCID: https://orcid.org/0000-0002-8663-6397

У статті наведено результати досліджень рекреаційно-оздоровчих насадженъ на територіі Кременецъкого району Тернопілъсъкої області. Загалом площа ијх лісів становить 5868,2 га.

Дослідження типологічної структури лісів здійснювали за методикою лісівничо-екологічної школи лісової типологї Алексєєва-Погребняка. Для побудови карти-схеми регіону дослідження використовували програму MapInfo Professional 12.0 та векторну карту України.

Типологічне різноманіття рекреачійно-оздоровчих насаджень представлено від суборів (В) до грудів (D). Так, серед них найбілъшою часткою представленні груди (72,9\% від загальної плоші вкритої лісовою рослинністю земель). Частка площі сугрудів становитъ 17,7\% від загалъної площі вкритої лісовою рослинністю земель, решта - субори $(9,4 \%)$.

На території дослідного об'єкта лісовпорядниками виділено 14 типів лісу. Так, у суборах виділено лише 2 mипи лісу, сугрудаx - 8 muпів лісу ma грудаx - 4 типи лісу.

Найбільш поширеним типом лісу на територї Кременецького району є свіна грабова діброва, яка представлена на площі 7 1,6\% від загальної площі вкритої лісовою рослинністю земель. Частка свіжого грабово-дубово-соснового сугруду сягає 17,1\%, дещо меншою часткою представлений свіжий дубово-сосновий субір - 9,4\%.

Видове різноманіття лісів представлено 22 видами дерев. Так, серед ицх деревних порід найбільиу площу займають дуб звичайний (Quеrсиs robur L.) - 40,6\% від загальної площі вкритої лісовою рослинністю земель та сосна звичайна (Pinus sylvestris L.) - 29,1\%.

Домінують насадження штучного походженням (78,0\% від загальної площі вкритої лісовою рослинністю земель), решта насаджень - природного походження (22,0\%).

Вікова структура насадженъ є розбалансованою. Домінують середнъовікові насадження (57,9\% від загальної площі вкритої лісовою рослинністю земель). Частка пристигаючих, молодняків та стиглих лісів коливається від 9,0 до 14,9\% від загальної плоші лісів.

За відносною повнотою домінують насадження з повнотою 0,7 1-0,8, шо складає 37,7\% від загалъної площі вкритої лісовою рослинністю земель. Частка насадження з повнотою 0,61-0,7 (29,9\%) i 0,81-0,9 (14,5\%) є дешо меншою.

За класами бонітету домінують насадження I класу бонітету - 51,3\% від загальної площі вкритої лісовою рослинністю земель. Так, частка II $і$ Ia та III класів бонітету варіює від 7,1 до 23,3\% від загальної плоші лісів.

Ключові слова: насадження, тип лісу, лісівничо-таксаиійні показники, лісова типологія, відносна повнота, клас бонітету.

\section{ЛITEРАТУРА}

1. Бондар О.Б., Ткач Л.І., Солодовник В.А. Лісівничо-таксаційна структура лісів у ДП «Кременецьке ЛГ». Поділъсъкий вісник: сілъсъке господарство, техніка, економіка. 2019. № 30. C. 15-23. DOI: https://doi.org/10.37406/2706-9052-2019-1-2

2. Ведмідь М.М., Распопіна С.П. Оцінка лісорослинного потенціалу земель. Методичний посібник. Київ: Видавничий дім «ЕКО-інформ», 2010. 80 с.

3. Калуцький I. Рекреаційно-оздоровчі лісові ресурси Івано-Франківщини та шляхи покращення їх використання. Гірсъка школа Українсъких Kарпат. 2013. № 10. С. 176-178.

4. Кутя M.M., Гірс О.А. Характеристика рекреаційних навантажень та рекреаційної місткості лісопаркових ландшафтів Києва. Науковий вісник НЛТУ України. 2012. Вип. 22.12. С. 86-90. 
5. Ліси зеленої зони м. Рівне та іх еколого-захисні функції / В.П. Ворон, С.В. Івашинюта, І.М. Коваль, М.А. Бондарук. Харків: Нове слово, 2008. 224 с.

6. Миклуш С.І., Миклуш Ю.С. Підходи до оцінки рекреаційних рівнинних букових лісів. Науковий вісник ЛТУ України. 2010. Вип. 20.9. С. 56-60.

7. Мусієнко С.І., Лук'янець В.А., Бондаренко В.В., Румянцев М.Г., Кобець О.В. Типологічне різноманіття рекреаційно-оздоровчих лісів Лівобережної України. Науковий вісник НЛТУ України. 2020. 30(5). C. 31-35. DOI: https://doi.org/10.36930/40300505

8. Павловська Т.С., Білецький Ю.В., Вілюра Т.С. Рекреаційно-оздоровчі ліси Волинської області. Науковий огляд. 2017. № 4 (36). С. 1-10.

9. Питуляк M., Питуляк M. Особливості рекреаційного лісокористування в Тернопільській області. Раціональне природокористування і охорона природи. Наукові записки. 2017. №2. С. 185-190.

10. Про затвердження Порядку поділу лісів на категорії та виділення особливо захисних лісових ділянок. URL: https://zakon.rada.gov.ua/laws/show/733-2007-\%D0\%BF\#Text (дата звернення: 12.05.2021).

11. Gerstenberg T., Baumeister C.F., Schraml U., Plieninger T. Hot routes in urban forests: The impact of multiple landscape features on recreational use intensity. Landscape and Urban Planning. 2020. 203. 103888. DOI: https://doi.org/10.1016/j.landurbplan.2020.103888

12. Oppliger J., Lieberherr E., Hegetschweiler K.T. Factors influencing teenagers' recreational forest use in a densely-populated region in Switzerland. Journal of Outdoor Recreation and Tourism. 2019.27. 100225. DOI: https://doi.org/10.1016/j.jort.2019.100225

13. Russo G.S., Eftim S.E., Goldstone A.E., Dufour A.P., Nappier S.P., Wade T.J. Evaluating health risks associated with exposure to ambient surface waters during recreational activities: A systematic review and meta-analysis. Water Research. 2020. 176. 115729. DOI: https://doi.org/10.1016/j.watres.2020.115729

14. Tavárez H., Elbakidze L. Valuing recreational enhancements in the San Patricio Urban Forest of Puerto Rico: A choice experiment approach. Forest Policy and Economics. 2019. 109. 102004. DOI: https://doi. org/10.1016/j.forpol.2019.102004

15. Tuffery L. The recreational services value of the nearby periurban forest versus the regional forest environment. Journal of Forest Economics. 2017. 28. P. 33-41. DOI: https://doi.org/10.1016/ j.jfe.2017.04.004

16. Tyrväinen L., Mäntymaa E., Juutinen A., Kurttila M., Ovaskainen V. Private landowners' preferences for trading forest landscape and recreational values: A choice experiment application in Kuusamo, Finland. Land Use Policy. 2021. 107. 104478. DOI: https://doi.org/10.1016/j.landusepol.2020.104478

\section{ВІДОМОСТІ ПРО АВТОРІВ}

Бондар Олександр Богданович, кандидат сільськогосподарських наук, старший викладач, Кременецька обласна гуманітарно-педагогічна академія ім. Тараса Шевченка (вул. Ліцейна, 1, м. Кременець, Тернопільська область, Україна, 47003; e-mail: olexandr.bondar@i.ua; ORCID: https://orcid.org/0000-0002-3448-8943)

Цицюра Неля Іванівна, кандидат біологічних наук, доцент, Кременецька обласна гуманітарнопедагогічна академія ім. Тараса Шевченка (вул. Ліцейна, 1, м. Кременець, Тернопільська область, Україна, 47003; e-mail: smaragds@ukr.net; ORCID: https://orcid.org/0000-0002-8663-6397) 